\title{
Vitamin D affects insulin sensitivity and $\beta$-cell function in obese non-diabetic youths
}

\author{
Domenico Corica ${ }^{1, *}$, Chiara Zusi ${ }^{2, *}$, Francesca Olivieri ${ }^{2}$, Marco Marigliano², Claudia Piona ${ }^{2}$, Elena Fornari ${ }^{2}$, \\ Anita Morandi' ${ }^{2}$, Massimiliano Corradi ${ }^{2}$, Emanuele Miraglia del Giudice ${ }^{3}$, Davide Gatti ${ }^{4}$, Maurizio Rossini ${ }^{4}$, \\ Riccardo C Bonadonna ${ }^{5}$ and Claudio Maffeis ${ }^{2}$
}

${ }^{1}$ Department of Human Pathology in Adulthood and Childhood 'G. Barresi', University of Messina, Messina, Italy, ${ }^{2}$ Pediatric Diabetes and Metabolic Disorders, Department of Surgical Sciences, Dentistry, Paediatrics and Gynaecology, University of Verona, Verona, Italy, ${ }^{3}$ Department of Woman, Child, and General and Specialized Surgery, University of Campania 'Luigi Vanvitelli', Naples, Italy, ${ }^{4}$ Rheumatology Unit, Department of Medicine, University of Verona, Verona, Italy, and ${ }^{5}$ Division of Endocrinology and Metabolic Diseases, Azienda Ospedaliero-Universitaria di Parma, Parma, Italy

*(D Corica and C Zusi contributed equally to this work)

Correspondence should be addressed to C Maffeis

Email

claudio.maffeis@univr.it

\section{Abstract}

Objective: Vitamin D may potentially play a central role in glucose homeostasis and $\beta$-cell function (BCF), although studies are not consistent. Aim of our study was to test the hypotheses of a direct relationship between vitamin $D$, insulin sensitivity (IS) and BCF in overweight and obese non-diabetic children.

Design and methods: Cross-sectional study carried out at the Childhood Obesity Outpatient Clinic, University Hospital of Verona. One hundred twenty-two Caucasian overweight and obese children (age: $12.8 \pm 0.2$ years) were enrolled. Exclusion criteria: genetic or endocrine causes of obesity, chronic diseases or therapies. Patients underwent oral glucose tolerance test. HOMA-IR, Matsuda index and insulinogenic index were calculated. BCF was reconstructed by mathematical modeling and described by Derivative and Proportional Control. Total 25-hydroxyvitamin $D$ and vitamin D-binding protein (VDBP) were measured. Two SNPs (rs4588 and rs7041) in the VDBP gene were studied, and bioavailable vitamin D (BVD) was calculated.

Results: Hypovitaminosis D was documented in 90\% of patients. Forty-seven subjects were homozygous for both SNPs. Total vitamin D was positively correlated with Matsuda index $(P=0.002)$, VDBP $(P=0.045)$, and negatively with BMI SDS $(P=0.043)$, HOMA-IR $(P=0.008)$, HOMA-B $(P=0.001)$, IGI $(P=0.007)$, derivative control $(P=0.036)$ and proportional control $(P=0.018)$. Total vitamin $D$, adjusted for age, gender, BMI SDS, puberty and seasonality of vitamin D measurement, was a predictor of Matsuda index, HOMA-IR, HOMA-B, IGI, proportional control (all $P<0.05)$. BVD was positively correlated with total vitamin $\mathrm{D}(P<0.001)$ and negatively with BMI SDS $(P=0.041)$.

Conclusions: Hypovitaminosis D negatively influences BCF and IS, suggesting that vitamin D levels might be implicated in glucose metabolism impairment in overweight and obese individuals.

\section{Introduction}

Vitamin D plays a central role in calcium and phosphorus homeostasis and bone metabolism, but it might exert also extra-skeletal actions, affecting pancreatic $\beta$-cell function (BCF) and glucose homeostasis. Vitamin D circulating levels are mainly influenced by geographic location of
European Journal of Endocrinology

(2019) 181, 439-450 residency, season and ethnicity $(1,2)$. Hypovitaminosis $\mathrm{D}$ is widely diffuse worldwide and is highly prevalent in children and adolescents $(1,3,4,5,6)$.

A higher incidence of low total vitamin D levels has been reported in obese compared to the general 
population, in both adults and children $(2,7,8,9,10$, 11). In a large cohort of US children Ganji et al. reported a prevalence of vitamin D deficiency of $21 \%$ in normalweight children, 29-34\% in overweight and obese children and $49 \%$ in severely obese children (12). Several mechanisms have been considered to explain the lower concentration of vitamin $\mathrm{D}$ in the obese, including inadequate diet consumption, decreased sun exposure due also to sedentary lifestyle, 25-hydroxy-vitamin D (25OHD) trapping in adipose tissue, although a combination of these factors is likely (10). Moreover, it has been suggested that, in spite of their low levels of total vitamin $\mathrm{D}$, obese children would have bioavailable vitamin D (BVD) levels similar to those of normal-weight children, due to reduced concentration of vitamin D-binding protein (VDBP) (13).

Consistent evidence suggests that vitamin D plays a central role in glucose metabolism. Vitamin D promotes the release of insulin, both directly by vitamin $\mathrm{D}$ receptors localized in pancreatic $\beta$-cells, as well as indirectly, by influencing plasma concentration of calcium and, consequently, calcium-dependent release of insulin (14). Furthermore, 1,25-dihydroxy-vitamin D $\left(1,25-\mathrm{OH}_{2} \mathrm{D}\right)$ promotes the transcription of insulin and its receptor genes, increasing its expression in liver, muscle and fat tissues and promotes the expression of glucose transporter GLUT4 in muscles and its translocation into adipocytes $(15,16,17,18)$. In vivo studies in animals documented that vitamin D deficiency causes an altered release of insulin in response to glucose (19). Furthermore, a protective effect of vitamin D on BCF, through a renin angiotensin systemsuppressing action, has been documented in murine models (20). However, a causal effect relationship between hypovitaminosis D and glycemic control, IR or diabetes risk is not completely accepted; indeed, randomized controlled studies, carried out in human cohorts, demonstrated no effect of vitamin D supplementation or maintenance of adequate vitamin $\mathrm{D}$ levels in glycemic control and beta-cell function in T2D and suggested that the association between vitamin $\mathrm{D}$ concentration and T2D might not be causal $(21,22,23,24)$.

Moreover, notwithstanding a role of vitamin D supplementation in modulation of hepatic insulin resistance (IR) through the effect of vitamin D-regulated pathways on hepatic lipogenesis and gluconeogenesis has been suggested a relationship between IR and vitamin D concentrations is not clearly demonstrated (9, $13,21,25,26)$.

The aim of our study was to test the hypotheses of a direct relationship between vitamin $\mathrm{D}$, both total vitamin
D and bioavailable vitamin D (BVD) concentrations, and insulin sensitivity (IS) and BCF in a sample of nondiabetic, overweight/obese children and adolescents.

\section{Subjects and methods}

\section{Subjects}

Study population included $122,12.8 \pm 2.3$ years old overweight and obese children and adolescents enrolled at the Pediatric Diabetes and Metabolic Disorders Unity, University Hospital, Verona (Italy). Inclusion criteria were Caucasian ethnicity, gender- and age-specific BMI cut-off for obesity reported in the WHO growth references (27). Exclusion criteria were genetic or endocrine causes of obesity, diabetes (American Diabetes Association criteria) (28), either pre-term or post-term birth, associated chronic diseases or chronic pharmacological therapies.

The protocol was approved by the Institutional Ethics Committee of Verona (Italy). Informed consent was obtained from children and their parents.

\section{Physical examination}

At recruitment, physical examination was performed according to standard procedures, as previously described (29). Weight was measured to the nearest $0.5 \mathrm{~kg}$ on standard physician's beam scales, with the child wearing only underwear and no shoes. Height was measured to the nearest $0.5 \mathrm{~cm}$ on a stadiometer without shoes, with the child's heels, buttocks, shoulders and head against the vertical wall with line of sight aligned horizontally. BMI was calculated as weight (in kilograms) divided by height (in meters) squared. BMI values were standardized using age and sex-specific median, standard deviation (s.D.) and power of the Box-Cox transformation (least mean square method) based on WHO growth references (27). Waist circumference was measured to the nearest $0.5 \mathrm{~cm}$ while the subjects were standing, after gently exhaling, as the minimal circumference measurable on the horizontal plane between the lowest portion of the rib cage and the iliac crest (30). Waist-to-height ratio (WHtR), an index of body fat distribution, was calculated as previously described (31). Pubertal stage was assessed according to Tanner criteria (32). Subjects were categorized into prepubertal (Tanner stage 1), pubertal (Tanner stage 2-4) and post-pubertal (Tanner stage 5) categories. Systolic blood pressure (SBP) and diastolic blood pressure (DBP) were recorded three times on the right arm in $\mathrm{mmHg}$ using a 
manual sphygmomanometer; for analysis, the average of three blood pressure values was used (33).

\section{Biochemical measurements}

Within 15 days from recruitment visit, all patients underwent fasting blood tests for measuring plasma glucose, serum insulin concentration, glycated hemoglobin (HbA1c), lipid profile, liver enzymes and albumin. Plasma glucose was measured with glucose oxidase method and HbA1c by immunoturbinometric assay (AccuChek Inform II and Cobas B101, Roche). Insulin and C-peptide levels were measured by enzyme-immunoassay (Mercodia AB, Sweden). Aspartate aminotransferase (AST), alanine aminotransferase (ALT), serum triglycerides, total cholesterol and high-density lipoprotein cholesterol (HDL-c) were measured by standard methods. Lowdensity lipoprotein cholesterol (LDL-c) was calculated using the Friedewald's equation. Serum albumin levels were measured in a spectrophotometer at $620 \mathrm{~nm}$ through colorimetric method (Sclavo Diagnostics International, Italy). Seasonality of blood collection was recorded as summer/fall and spring/winter.

Furthermore, patients underwent a prolonged oral glucose tolerance test (modified-OGTT), performed with standard method $(1.75 \mathrm{~g} / \mathrm{kg}$ of body weight, up to a maximum of $75 \mathrm{~g}$ ) according to the ADA guidelines (28), with sampling at times of $-10,0,+10,+20,+30,+45,+60$, $+90,+120,+150,+180 \mathrm{~min}$ for measurements of glucose, insulin and C-peptide. Blood samples were collected in SST II or EDTA tubes and centrifuged at $1300 \boldsymbol{g}$ for $10 \mathrm{~min}$ after collection; serum and plasma were stored at $-80^{\circ} \mathrm{C}$ until analyzed. No subjects had diabetes according on ADA definition.

BCF was reconstructed by mathematical modeling, as described by Bonadonna et al. (34). By this method, BCF is described by two parameters: derivative (or dynamic) control, i.e. the response of the $\beta$-cell to the rate of glucose increase of $1 \mathrm{mmol} / \mathrm{L}$ per minute that lasts for $1 \mathrm{~min}$ (expression of 1 st phase of insulin secretion) and proportional (or static) control, i.e. the stimulus-response curve linking of the $\beta$-cell to glucose concentration per se (expression of 2 nd phase of insulin secretion).

\section{OGTT-derived indices}

The following OGTT-derived indices were calculated:

- Homeostasis model assessment for insulin resistance (HOMA-IR) was calculated as (insulin $(\mathrm{mU} / \mathrm{L}) \times$ glucose $(\mathrm{mg} / \mathrm{dL})) / 405$, and used as a fasting biomarker of IR (35).

- Homeostasis model assessment for BCF (HOMA-B) was performed as $((360 \times$ insulin $(\mathrm{mU} / \mathrm{L})) /($ glucose $(\mathrm{mg} / \mathrm{dL})-63))$ and considered as a measure of BCF (36).

- Insulinogenic index (IGI), assessed as (insulin30 $(\mathrm{mU} / \mathrm{L})-$ insulin0 $\quad(\mathrm{mU} / \mathrm{L})) /($ glucose30 $\quad(\mathrm{mg} / \mathrm{dL})$ - glucose0 $(\mathrm{mg} / \mathrm{dL})$ ), was selected as a biomarker of insulin bioavailability in response to oral glucose (37).

- Matsuda index: 10 000/((glucose0' $(\mathrm{mg} / \mathrm{dL}) \times$ insulin0' $(\mathrm{mU} / \mathrm{L})) \times($ mean OGTT glucose concentration $(\mathrm{mg} / \mathrm{dL}))$ $\times($ mean OGTT insulin concentration $(\mathrm{mU} / \mathrm{L})))^{1 / 2}$; it was used as a postprandial biomarker of IS (38).

- Mathematical modeling of glucose and C-peptide curves following the OGTT was performed and derivative and proportional controls of BCF were computed (39).

\section{Genotyping}

Genomic DNA was extracted from peripheral blood leukocytes using salting-out procedures. Genotyping was carried out by a predesigned TaqMan probe (Applied Biosystem), according to the manufacturers' protocol, with a $>99 \%$ positive call-rate. Polymorphism genotyping was performed using 7900 HT Real Time PCR (Applied Biosystem). We genotyped two common SNPs (rs4588 and rs7041) in the coding region of the VDBP gene.

\section{Vitamin D measurements}

Total vitamin D and parathyroid hormone (PTH) were measured through chemiluminescent method (IDSiSYS Multi Discipline automated analyzer; IDS-iSYS, Immunodiagnostic System, Boldon, UK). Vitamin D deficiency, insufficiency and sufficiency were defined as a $25(\mathrm{OH}) \mathrm{D}$ levels $<20,20-29$ and $\geq 30 \mathrm{ng} / \mathrm{mL}$, respectively (40). Vitamin D-binding protein was measured by ELISA method (R\&D Systems) $(13,41)$.

Forty-seven out of 122 subjects were in homozygoses for the two analyzed SNPs. A single genotype-specific binding affinity constant on the basis of the presence of a single $V D B P$ variant according to the equation reported by Powe et al. was applied (41). In these subjects BVDdependent concentration was calculated.

\section{Statistical analysis}

Patients' baseline characteristics are reported as mean \pm S.D. Kolmogorov-Smirnov test was used to assess 
normal distribution of variables. Skewed variables were transformed (natural log transformed or square root transformed, if and as needed) to correct for non-Gaussian distribution, unless deviations from the Gaussian distribution could not be corrected by transformation. Spearman correlation was applied to normal and skewed distributed variables. Student's t-test, Mann-Whitney or chi-squared test were used to detect the differences among patients stratified by gender or total vitamin D groups.

Multiple regression analyses, using HOMA-IR, HOMA-B, Matsuda index, IGI, derivative control or proportional control as dependent variables, were run. Two models were calculated: in the first, total vitamin D was considered as independent variable together with age, gender, pubertal stage, BMI SDS and season of vitamin $\mathrm{D}$ measurement, in the second one, total vitamin $\mathrm{D}$ was replaced by BVD. Covariates included in regression models were selected as potential confounding factors based on their biological plausibility.

A $P$ value $<0.05$ was considered as a nominal statistical significance. Benjamini-Hochberg (BH) step-up procedure was applied for multiple test adjustment (42). All analyses were performed using SPSS v.22.0 (SPSS).

\section{Results}

A sample of 122 subjects (69 males, 53 females) with a mean age of $12.8 \pm 2.3$ years and a mean BMI SDS of $2.9 \pm 0.8$ was recruited. Anthropometric and metabolic characteristics of the study population are showed in Table 1. Males had higher waist circumference $(P=0.009)$, WHtR $(P=0.004), 2$-h-plasma insulin $(P=0.039)$, ALT $(P=0.009)$, AST $(P=0.015)$ and HOMA-B $(P=0.033)$ than females. No other nominal significant differences for others variables between genders were found.

Vitamin D insufficiency (defined as total vitamin D 20-29 $\mathrm{ng} / \mathrm{mL}$ ) and deficiency (defined as total vitamin $\mathrm{D}<20 \mathrm{ng} / \mathrm{mL})$ were found in $50 \%(n=61)$ and $40.2 \%$ $(n=49)$ of children, respectively. No significant differences between genders were found.

Splitting subjects into two groups (group A: subjects with vitamin D deficiency; group B: subjects with normal vitamin $\mathrm{D}$ and vitamin $\mathrm{D}$ insufficiency), we found nominal significant differences between groups in BMI $(P=0.007)$, PTH $(P=0.023)$, HOMA-IR $(P=0.002)$, HOMA-B $(P=0.008)$, IGI $(P=0.041)$, Matsuda index $(P=0.001)$ and proportional control $(P=0.035)$ (Table 2$)$.

None of these differences stayed statistically significant after multiple test adjustment.
Genotyping for two common single-nucleotide polymorphisms in the coding region of the VDBP gene (rs4588 and rs7041), we detected 47 subjects homozygous for rs4588 and rs7041 VDBP polymorphisms: 25 homozygous for Gc1S/Gc1S alleles, 4 for Gc1F/Gc1F and 18 for Gc2/Gc2. Bioavailable vitamin D in this group of 47 subjects was $4.30 \pm 0.31 \mathrm{ng} / \mathrm{mL}$.

\section{Correlation analysis}

Results of the correlation analyses are reported in Table 3. Total vitamin $\mathrm{D}$ was positively correlated with BVD, also after multiple test adjustment $(r=0.68, P$-adj=0.0009), whereas was nominally correlated with Matsuda index $(r=0.28, \quad P=0.002)$, and negatively with BMI SDS $(r=-0.18, \quad P=0.043)$, HOMA-IR $\quad(r=-0.24, \quad P=0.008)$, IGI $(r=-0.25, P=0.007)$, derivative control $(r=-0.20$, $P=0.036)$, proportional control $(r=-0.22, P=0.018)$ and fasting plasma insulin.

Bioavailable vitamin D was positively correlated with Matsuda index $(r=0.25, P=0.026)$ and negatively with BMI SDS $(r=-0.29, P=0.041)$, IGI $(r=-0.38, P=0.007)$, derivative control $(r=-0.29, \quad P=0.05)$, proportional control $(r=-0.31, P=0.036)$ and plasma insulin at time $30^{\prime}(r=-0.43, P=0.026)$ of the modified OGTT.

Vitamin D-binding protein did not significantly correlate with any other variable except BVD, that remained significant after multiple test adjustment $(r=-0.51, P$-adj=0.023), and total vitamin D $(r=0.17$, $P=0.045)$.

Total vitamin $\mathrm{D}$ and $\mathrm{BVD}$ did not significantly correlate with waist circumference, WHtR, systolic and DBP, HbA1c, lipid profile and plasma glucose concentration during modified OGTT.

\section{Regression analysis}

Multivariate regression analysis (Table 4) showed that total vitamin $\mathrm{D}$, independently from age, gender, BMI SDS, pubertal stage, season of vitamin D measurement, was positively associated with Matsuda index $(P=0.020)$ and negatively with HOMA-IR $(P=0.038)$, HOMA-B $(P=0.012)$, IGI $(P=0.042)$ and proportional control $(P=0.045)$.

Bioavailable vitamin D, independently from age, gender, BMI SDS, pubertal stage, season of vitamin D measurement, was inversely associated with IGI $(P=0.034)$ (Table 5). None of these associations remained statistically significant after multiple test adjustment. 
Table 1 Physical and biochemical features of the total sample and comparison analysis according to genders. Data are expressed as means \pm S.D. or number and percentage, $n$ (\%). Differences between gender were tested by Student's $t$-test for normally distributed variables and the Mann-Whitney test for skewed distributed variables or using $\chi^{2}$ test for categorical variables. Nominal $P$ values were reported.

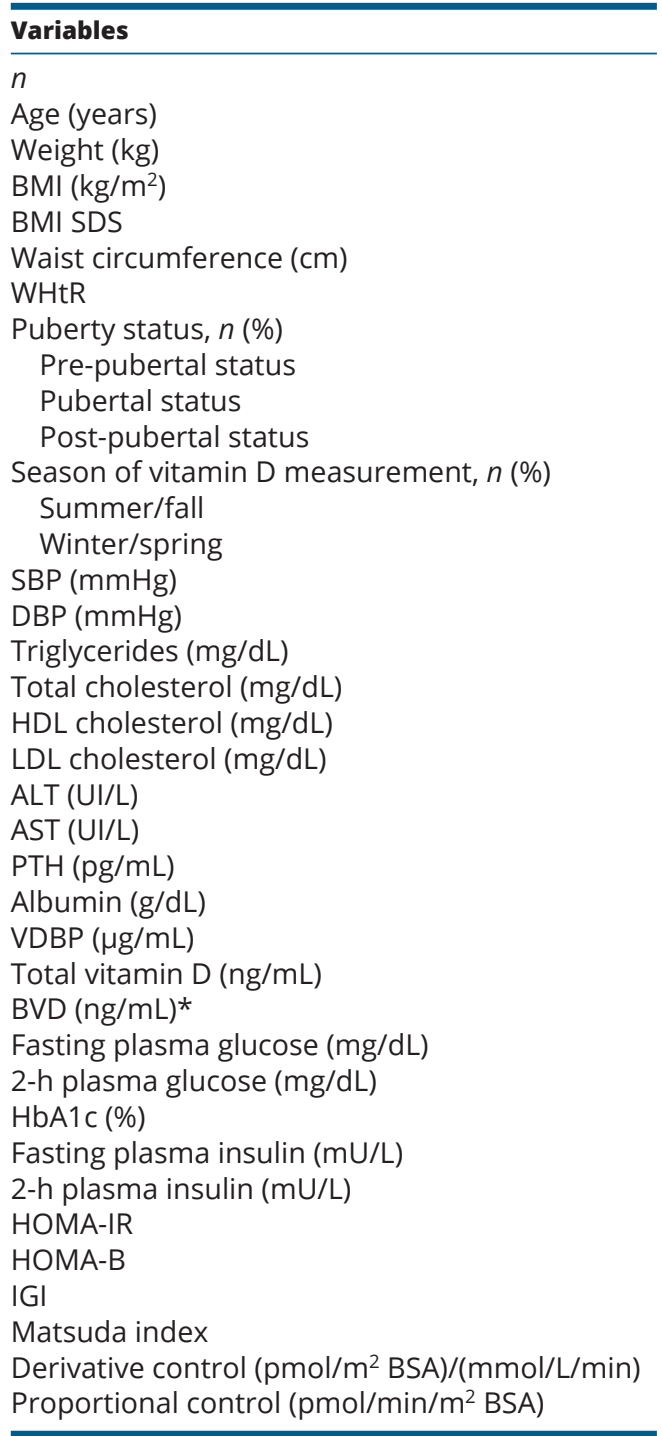

\begin{tabular}{c}
\hline Total \\
\hline 122 \\
$12.8 \pm 2.3$ \\
$83.3 \pm 25.2$ \\
$31.9 \pm 7.0$ \\
$2.93 \pm 0.77$ \\
$98.8 \pm 15.9$ \\
$0.62 \pm 0.07$ \\
$24(19.8)$ \\
$49(40.1)$ \\
$49(40.1)$ \\
$59(48.4)$ \\
$63(51.6)$ \\
$119.4 \pm 13.7$ \\
$70.2 \pm 10.4$ \\
$85.9 \pm 69.2$ \\
$155.0 \pm 31.1$ \\
$44.0 \pm 9.9$ \\
$90.0 \pm 29.0$ \\
$31.8 \pm 19.8$ \\
$21.8 \pm 9.9$ \\
$35.2 \pm 12.9$ \\
$5.29 \pm 0.30$ \\
$201.8 \pm 22.5$ \\
$19.66 \pm 7.8$ \\
$4.30 \pm 2.06$ \\
$91.0 \pm 7.9$ \\
$113.4 \pm 19.6$ \\
$5.54 \pm 0.35$ \\
$23.8 \pm 13.2$ \\
$137.6 \pm 116.9$ \\
$5.41 \pm 3.10$ \\
$313.8 \pm 186.1$ \\
$3.43 \pm 2.28$ \\
$2.38 \pm 1.76$ \\
$2252.4 \pm 2049.1$ \\
$135.3 \pm 82.4$ \\
\end{tabular}

\begin{tabular}{c}
\hline Male \\
\hline 69 \\
$13.0 \pm 2.4$ \\
$85.1 \pm 28.3$ \\
$31.8 \pm 7.7$ \\
$2.97 \pm 0.85$ \\
$103.2 \pm 17.7$ \\
$0.65 \pm 0.08$ \\
$15(21.7)$ \\
$34(49.3)$ \\
$20(29.0)$ \\
$34(50)$ \\
$34(50)$ \\
$121.1 \pm 16.6$ \\
$70.3 \pm 11.8$ \\
$82.8 \pm 67.7$ \\
$156.1 \pm 34.3$ \\
$44.9 \pm 9.8$ \\
$92.4 \pm 31.7$ \\
$35.6 \pm 20.7$ \\
$23.2 \pm 9.6$ \\
$34.5 \pm 12.7$ \\
$5.30 \pm 0.27$ \\
$199.6 \pm 21.4$ \\
$20.59 \pm 7.63$ \\
$4.52 \pm 2.23$ \\
$92.0 \pm 6.6$ \\
$113.8 \pm 22.0$ \\
$5.54 \pm 0.33$ \\
$22.6 \pm 13.0$ \\
$122.5 \pm 86.2$ \\
$5.21 \pm 3.14$ \\
$282.4 \pm 160.2$ \\
$3.34 \pm 2.41$ \\
$2.55 \pm 2.04$ \\
$2351.4 \pm 2474.6$ \\
$131.8 \pm 86.9$ \\
\\
\end{tabular}

\begin{tabular}{|c|c|}
\hline Female & $P$ value \\
\hline 53 & \\
\hline $12.6 \pm 1.9$ & 0.375 \\
\hline $80.9 \pm 20.6$ & 0.370 \\
\hline $32.0 \pm 5.9$ & 0.891 \\
\hline $2.87 \pm 0.66$ & 0.483 \\
\hline $93.6 \pm 11.6$ & 0.009 \\
\hline \multirow{2}{*}{$0.60 \pm 0.06$} & 0.004 \\
\hline & 0.039 \\
\hline \multicolumn{2}{|l|}{$9(17.0)$} \\
\hline \multicolumn{2}{|l|}{$15(28.3)$} \\
\hline \multicolumn{2}{|l|}{$29(54.7)$} \\
\hline & 0.672 \\
\hline \multicolumn{2}{|l|}{$25(46.3)$} \\
\hline \multicolumn{2}{|l|}{$29(53.7)$} \\
\hline $117.3 \pm 8.6$ & 0.085 \\
\hline $70.1 \pm 8.3$ & 0.679 \\
\hline $90.0 \pm 71.6$ & 0.370 \\
\hline $153.5 \pm 26.4$ & 0.672 \\
\hline $42.7 \pm 10.1$ & 0.293 \\
\hline $86.9 \pm 25.1$ & 0.351 \\
\hline $26.7 \pm 17.5$ & 0.009 \\
\hline $19.8 \pm 9.9$ & 0.015 \\
\hline $36.0 \pm 13.3$ & 0.526 \\
\hline $5.28 \pm 0.33$ & 0.538 \\
\hline $204.6 \pm 23.9$ & 0.227 \\
\hline $18.45 \pm 7.82$ & 0.132 \\
\hline $4.00 \pm 1.79$ & 0.408 \\
\hline $89.7 \pm 7.2$ & 0.072 \\
\hline $112.9 \pm 16.1$ & 0.963 \\
\hline $5.53 \pm 0.38$ & 0.872 \\
\hline $25.3 \pm 13.4$ & 0.262 \\
\hline $156.8 \pm 145.7$ & 0.039 \\
\hline $5.66 \pm 3.05$ & 0.258 \\
\hline $355.6 \pm 210.3$ & 0.033 \\
\hline $3.54 \pm 2.12$ & 0.466 \\
\hline $2.17 \pm 1.32$ & 0.369 \\
\hline $2132.5 \pm 1383.8$ & 0.669 \\
\hline $139.6 \pm 77.3$ & 0.310 \\
\hline
\end{tabular}

${ }^{*} n=47$ subjects $(M=28, F=19)$.

BMI, body mass index; BVD, bioavailable vitamin D in 47 subjects genotyped for VDBP variants; DBP, diastolic blood pressure; HbA1c, glycated hemoglobin; HOMA-B, homeostasis model assessment for $\beta$-cell function; HOMA-IR, homeostasis model assessment for insulin resistance; IGI, insulinogenic index; PTH, parathyroid hormone; SBP, systolic blood pressure; VDBP, vitamin D-binding protein; WHtR, waist-to-height ratio.

\section{Discussion}

The main finding of this study is the significant association between total vitamin $\mathrm{D}$ and IS, IR and insulin secretion indices, adjusting for confounders, supporting the hypothesis of a potential direct effect of vitamin D status on IS, IR and BCF, in non-diabetic, overweight and obese children and adolescents.
Vitamin D affects BCF through several pathways: directly, through interaction with vitamin $\mathrm{D}$ receptor localized on $\beta$-cells, and indirectly, via regulation of serum calcium concentration and calcium flux through the $\beta$ cell, therefore influencing both insulin synthesis and secretion (14). Vitamin D promotes also insulin receptor gene transcription and the expression of this receptor in peripheral insulin-target tissues (liver, skeletal muscle, 
Table 2 Comparison analysis of physical and biochemical characteristics among subjects with vitamin D deficiency (Group A) vs subjects with normal and insufficiency vitamin D (Group B). Patients were divided in the two groups according to total vitamin D value. Data are expressed as means \pm S.D. or number and percentage $n$ (\%). Differences between gender were tested by Student's $t$-test for normally distributed variables and the Mann-Whitney test for skewed distributed variables or using $\chi^{2}$-test for categorical variables. Nominal $P$ values were reported.

\begin{tabular}{|c|}
\hline Variables \\
\hline Age (years) \\
\hline BMI $\left(\mathrm{kg} / \mathrm{m}^{2}\right)$ \\
\hline BMI SDS \\
\hline Waist circumference $(\mathrm{cm})$ \\
\hline WHtR \\
\hline Puberty status, $n(\%)$ \\
\hline Pre-pubertal status \\
\hline Pubertal status \\
\hline Post-pubertal status \\
\hline Season of vitamin D measurement, $n(\%)$ \\
\hline Summer/fall \\
\hline Winter/spring \\
\hline $\mathrm{SBP}(\mathrm{mmHg})$ \\
\hline $\mathrm{DBP}(\mathrm{mmHg})$ \\
\hline Triglycerides (mg/dL) \\
\hline Total cholesterol (mg/dL) \\
\hline HDL cholesterol (mg/dL) \\
\hline LDL cholesterol (mg/dL) \\
\hline PTH (pg/mL) \\
\hline Fasting plasma glucose (mg/dL) \\
\hline 2-h plasma glucose $(\mathrm{mg} / \mathrm{dL})$ \\
\hline $\mathrm{HbA} 1 \mathrm{c}(\%)$ \\
\hline Fasting plasma insulin (mU/L) \\
\hline 2-h plasma insulin (mU/L) \\
\hline HOMA-IR \\
\hline HOMA-B \\
\hline IGI \\
\hline Matsuda index \\
\hline Derivative control (pmol/m² BSA)/(mmol/L/min) \\
\hline Proportional control ( $\left.\mathrm{pmol} / \mathrm{min} / \mathrm{m}^{2} \mathrm{BSA}\right)$ \\
\hline
\end{tabular}

\begin{tabular}{c}
\hline Group A $(n=61)$ \\
\hline $13.3 \pm 2.3$ \\
$33.6 \pm 7.3$ \\
$3.05 \pm 0.73$ \\
$100.6 \pm 15.2$ \\
$0.63 \pm 0.08$ \\
$10(16.4)$ \\
$23(37.7)$
\end{tabular}

28 (45.9)

$21(33.3)$

$42(66.7)$

$120.6 \pm 14.9$

$71.6 \pm 12.4$

$83.40 \pm 59.5$

$153.5 \pm 34.3$

$42.1 \pm 9.1$

$90.8 \pm 31.7$

$37.8 \pm 12.7$

$91.2 \pm 7.3$

$113.4 \pm 19.3$

$5.51 \pm 0.34$

$27.2 \pm 13.3$

$166.0 \pm 139.9$

$6.20 \pm 3.22$

$358.5 \pm 189.8$

$3.79 \pm 2.19$

$1.91 \pm 1.15$

$2392.6 \pm 1691.3$

$151.5 \pm 90.4$

\begin{tabular}{c}
\hline Group B $(n=61)$ \\
\hline $12.4 \pm 2.2$ \\
$30.2 \pm 6.2$ \\
$2.81 \pm 0.80$ \\
$96.7 \pm 16.6$ \\
$0.61 \pm 0.07$
\end{tabular}

$P$ value

0.075

0.007 *

0.088

0.306

0.437

0.022

$14(23.0)$

$26(42.6)$

21 (34.4)

38 (64.4)

21 (35.6)

$118.2 \pm 12.4$

$68.8 \pm 7.7$

$88.46 \pm 78.2$

$156.7+27.4$

$46.0 \pm 10.5$

$89.2 \pm 26.1$

$32.5+12.7$

$90.9 \pm 6.7$

$113.3 \pm 20.1$

$5.56 \pm 0.37$

$20.3 \pm 12.2$

$108.2 \pm 77.7$

$4.60 \pm 2.78$

$268.3 \pm 172.3$

$3.06 \pm 2.33$

$2.87 \pm 2.12$

$2114.6 \pm 2355.6$

0.001 *

$119.4 \pm 71.0$
0.180

0.691

0.600

0.052

0.781

0.023

0.814

0.980

0.424

0.004 *

0.007

0.002 *

0.008

0.041

0.001 *

0.151

0.035

*Significant $P$ values after further adjustment for multiplicity (by using the Benjamini-Hochberg step-up procedure).

$\mathrm{BMI}$, body mass index; DBP, diastolic blood pressure; HbA1c, glycated hemoglobin; HOMA-B, homeostasis model assessment for $\beta$-cell function; HOMA-IR, homeostasis model assessment for insulin resistance; IGI, insulinogenic index; SBP, systolic blood pressure; WHtR, waist-to-height ratio.

and adipose tissue) $(15,16,17,18)$. Moreover, vitamin $\mathrm{D}$ would affect insulin levels reducing inflammationinduced $\beta$-cell apoptosis by an immune-regulation effect (43). Accordingly, low vitamin D levels seems to be related to defective insulin secretion, reduced glucose homeostasis, and increased risk of metabolic syndrome and T2D $(44,45)$.

Several studies investigated mechanisms through vitamin D could influence $\beta$-cell function and IS, different from direct effects on calcium metabolism. In two studies including murine models, a suppressing effect of vitamin D on pancreatic renin angiotensin system, that is involved in islet cell proliferation and apoptosis, seems to determine a protective effect on BCF $(20,46,47)$. Particularly, mice with hypovitaminosis D presented increased expression of renin angiotensin system components, impaired $\beta$-cell gene transcription and impaired glucose tolerance (47). Accordingly, isolated murine pancreatic islets, incubated ex vivo under high-glucose conditions, exhibited an increase in renin angiotensin system components expression and production, prevented by calcitriol administration that contemporarily promoted the $\beta$-cell glucose-stimulated insulin secretion (20).

Considering the close link between IR and the pathogenesis of steatohepatitis in obese and diabetic patients, vitamin $\mathrm{D}$ appears to be also involved in the regulation of hepatic insulin resistance and development of nonalcoholic fatty liver disease (NAFLD) (48). Hypovitaminosis D and NAFLD frequently coexist in obese models, and growing evidences supported a potentially 
Table 3 Spearman correlation analysis among total vitamin D, BVD and clinical and biochemical variables.

\begin{tabular}{|c|c|c|c|c|}
\hline \multirow[b]{2}{*}{ Variables } & \multicolumn{2}{|c|}{ Total vitamin D } & \multicolumn{2}{|c|}{ BVD } \\
\hline & $r$ & $P$ & $r$ & $P$ \\
\hline Age (years) & -0.21 & 0.020 & -0.13 & 0.385 \\
\hline Weight (kg) & -0.19 & 0.036 & -0.18 & 0.225 \\
\hline $\mathrm{BMI}\left(\mathrm{kg} / \mathrm{m}^{2}\right)$ & -0.24 & 0.007 & -0.23 & 0.118 \\
\hline BMI SDS & -0.18 & 0.043 & -0.29 & 0.041 \\
\hline WC (cm) & -0.07 & 0.557 & -0.12 & 0.557 \\
\hline WHtR & -0.04 & 0.722 & 0.06 & 0.752 \\
\hline $\mathrm{SBP}(\mathrm{mmHg})$ & 0.03 & 0.786 & 0.01 & 0.972 \\
\hline $\mathrm{DBP}(\mathrm{mmHg})$ & -0.11 & 0.269 & 0.08 & 0.637 \\
\hline Triglycerides (mg/dL) & 0.06 & 0.564 & -0.22 & 0.704 \\
\hline Total-c (mg/dL) & 0.04 & 0.713 & -0.04 & 0.764 \\
\hline $\mathrm{HDL}-\mathrm{c}(\mathrm{mg} / \mathrm{dL})$ & 0.17 & 0.092 & 0.19 & 0.497 \\
\hline LDL-c (mg/dL) & -0.09 & 0.512 & -0.10 & 0.743 \\
\hline AST (UI/L) & -0.06 & 0.653 & 0.13 & 0.825 \\
\hline ALT (UI/L) & -0.01 & 0.917 & 0.05 & 0.743 \\
\hline PTH (pg/mL) & -0.31 & $0.001 *$ & -0.07 & 0.666 \\
\hline HOMA-IR & -0.24 & 0.008 & -0.17 & 0.140 \\
\hline HOMA-B & -0.31 & $0.001 *$ & -0.26 & 0.084 \\
\hline MATSUDA index & 0.28 & $0.002^{*}$ & 0.25 & 0.026 \\
\hline IGI & -0.25 & 0.007 & -0.38 & 0.007 \\
\hline Derivative control & -0.20 & 0.036 & -0.29 & 0.050 \\
\hline Proportional control & -0.22 & 0.018 & -0.31 & 0.036 \\
\hline FPG (mg/dL) & 0.06 & 0.512 & 0.18 & 0.558 \\
\hline $\mathrm{FPI}(\mathrm{mU} / \mathrm{L})$ & -0.25 & $0.004 *$ & -0.22 & 0.091 \\
\hline HbA1c (\%) & 0.12 & 0.110 & 0.13 & 0.396 \\
\hline Total vit $\mathrm{D}(\mathrm{ng} / \mathrm{mL})$ & - & - & 0.68 & $<0.001$ * \\
\hline $\mathrm{BVD}(\mathrm{ng} / \mathrm{mL})$ & 0.68 & $<0.001 *$ & - & - \\
\hline $\operatorname{VDBP}(\mu \mathrm{g} / \mathrm{mL})$ & 0.17 & 0.045 & -0.51 & $<0.001 *$ \\
\hline
\end{tabular}

Nominal $P$ values were reported.

* Significant $P$ values after further adjustment for multiplicity (by using the Benjamini-Hochberg step-up procedure).

$B M I$, body mass index; BVD, bioavailable vitamin $D$ in 47 subjects genotyped for VDBP variants; FPG, fasting plasma glucose; FPI, fasting plasma insulin; HbA1c, glycated hemoglobin; HOMA-B, homeostasis model assessment for $\beta$-cell function; HOMA-IR, homeostasis model assessment for insulin resistance; IGI, insulinogenic index; Total-c, total cholesterol; VDBP, vitamin D-binding protein; WC, waist circumference; WHtR, waist-to-height ratio.

causative relationship between these two conditions. In murine models, vitamin $\mathrm{D}$ shows a protective effect against liver damage and steatosis, by inhibiting lipid accumulation through autophagy and by attenuating oxidative stress $(49,50)$. Treatment with $1,25-\mathrm{OH}_{2} \mathrm{D}$ seemed to improve abnormal hepatic lipid and glucose production in T2D mice and seemed to reduce, through activation of $\mathrm{Ca}^{+} /$calcium-calmodulin protein kinasebeta/AMP-activated protein kinase pathways, hepatic triglyceride storage and glucose output under in vitro insulin-resistant condition (51). These results support the regulatory action of vitamin $\mathrm{D}$ on glucose and lipid metabolism and, consequently, on IR and sensitivity.

Accordingly, hypovitaminosis D was significantly associated with histologically proven NAFLD and vitamin
D seems to be protective against progression from NAFLD to nonalcoholic steatohepatitis (NASH), inhibiting the proliferation hepatic stellate cells, responsible for collagen deposition and fibrosis $(52,53)$. However, conversely, other studies have not demonstrated an association between vitamin $\mathrm{D}$ deficiency and histological characteristics or severity of NAFLD neither positive effect of vitamin D supplementation on hepatic fat content or markers of hepatic injury or IS $(54,55,56,57)$. Therefore, on the light of these conflicting results, further prospective randomized clinical trials in humans will be necessary to establish the role of vitamin $\mathrm{D}$ concentration and supplementation in NAFLD and in hepatic IR.

In our cohort of overweight and obese children and adolescents, we found a high prevalence of hypovitaminosis D (90\%), according with others $(2,9)$. However, we found a direct correlation between total vitamin D and BVD, supporting the hypothesis that bioavailability of vitamin $\mathrm{D}$ is reduced proportionally to the reduction of total vitamin D. In our study, the first that simultaneously investigated the association between total vitamin D, BVD and IS, IR and BCF in overweight and obese, non-diabetic, children and adolescents, we found that total vitamin D was significant predictor of IS, IR and BCF, in term of both HOMA-B and the 2 nd phase of insulin secretion (proportional control). These relationships were independent from age, gender, pubertal stage, season of vitamin D measurement and BMI SDS. Our data confirm previous studies demonstrating an inverse association between total vitamin $\mathrm{D}$ and $\operatorname{BMI} \operatorname{SDS}(2,7,9)$. Moreover, for the first time, we found that also the bioavailable form of vitamin D is inversely associated with BMI SDS, suggesting a direct relationship between the severity of overweight and the degree of hypovitaminosis D.

IR and an altered BCF are two conditions that usually preceded the development of abnormal glucose tolerance and type 2 diabetes (T2D). Our data contribute to support the hypothesis that hypovitaminosis D might be implicated in the pathogenesis of T2D in overweight and obese individuals, who are at risk of glucose metabolism impairment $(37,38)$. Previous studies in adults provided evidences on the relationships between vitamin $\mathrm{D}$ and $\mathrm{T} 2 \mathrm{D}$, sustaining the positive effect of normal vitamin $\mathrm{D}$ concentrations in reducing risk of T2D $(39,40,41,42)$, as well as the favorable effects of vitamin D supplementation both in reducing the risk of developing IR and T2D and in improving the glycemic control in patients with T2D $(24,43,44,45)$. In a meta-analysis, Parker et al. reported a significant association between high levels of vitamin $\mathrm{D}$ and a $55 \%$ of reduction on the risk of having T2D 
Table 4 Multivariate linear regression analysis in the total sample for HOMA-IR, HOMA-B, Matsuda index, IGI, derivative control and proportional control using total vitamin D, age, gender, BMI SDS, pubertal stage and seasonality of vitamin D measurement as independent variables.

\begin{tabular}{|c|c|}
\hline Dependent variables & Independent variables \\
\hline HOMA-IR & $\begin{array}{l}\text { Total vitamin D } \\
\text { Age } \\
\text { Gender } \\
\text { BMI SDS } \\
\text { Pubertal stage } \\
\text { Seasonality }\end{array}$ \\
\hline HOMA-B & $\begin{array}{l}\text { Total vitamin D } \\
\text { Age } \\
\text { Gender } \\
\text { BMI SDS } \\
\text { Pubertal stage } \\
\text { Seasonality }\end{array}$ \\
\hline Matsuda index & $\begin{array}{l}\text { Total vitamin D } \\
\text { Age } \\
\text { Gender } \\
\text { BMI SDS } \\
\text { Pubertal stage } \\
\text { Seasonality }\end{array}$ \\
\hline IGI & $\begin{array}{l}\text { Total vitamin D } \\
\text { Age } \\
\text { Gender } \\
\text { BMI SDS } \\
\text { Pubertal stage } \\
\text { Seasonality }\end{array}$ \\
\hline Derivative control & $\begin{array}{l}\text { Total vitamin D } \\
\text { Age } \\
\text { Gender } \\
\text { BMI SDS } \\
\text { Pubertal stage } \\
\text { Seasonality }\end{array}$ \\
\hline Proportional control & $\begin{array}{l}\text { Total vitamin D } \\
\text { Age } \\
\text { Gender } \\
\text { BMI SDS } \\
\text { Pubertal stage } \\
\text { Seasonality }\end{array}$ \\
\hline
\end{tabular}

\begin{tabular}{|c|}
\hline $\boldsymbol{\beta}$ coefficient $(95 \% \mathrm{Cls})$ \\
\hline$-0.01(-0.01$ to 0.00$)$ \\
\hline $0.01(-0.03$ to 0.04$)$ \\
\hline $0.07(-0.03$ to 0.17$)$ \\
\hline $0.15(0.09-0.21)$ \\
\hline $0.01(-0.09$ to 0.10$)$ \\
\hline $0.05(-0.04$ to 0.13$)$ \\
\hline$-0.02(-0.03$ to -0.004$)$ \\
\hline $0.03(-0.04$ to 0.09$)$ \\
\hline $0.24(0.04-0.44)$ \\
\hline $0.30(0.17$ to 0.43$)$ \\
\hline $0.08(-0.12$ to 0.28$)$ \\
\hline$-0.10(-0.31$ to 0.11$)$ \\
\hline $0.01(0.001-0.01)$ \\
\hline $0.004(-0.03$ to 0.03$)$ \\
\hline$-0.04(-0.14$ to 0.05$)$ \\
\hline$-0.14(-0.20$ to -0.08$)$ \\
\hline$-0.01(-0.01$ to 0.08$)$ \\
\hline$-0.04(-0.13$ to 0.06$)$ \\
\hline$-0.02(-0.03$ to -0.001$)$ \\
\hline$-0.01(-0.09$ to 0.07$)$ \\
\hline $0.04(-0.21$ to 0.29$)$ \\
\hline $0.17(0.02-0.33)$ \\
\hline $0.02(-0.21$ to 0.25$)$ \\
\hline $0.06(-0.18$ to 0.30$)$ \\
\hline$-0.31(-0.92$ to 0.30$)$ \\
\hline $0.27(-2.73$ to 3.27$)$ \\
\hline$-0.51(-9.87$ to 8.85$)$ \\
\hline $2.94(-2.94$ to 8.81$)$ \\
\hline $3.08(-5.53$ to 11.69$)$ \\
\hline$-3.83(-12.93$ to 5.28$)$ \\
\hline$-0.01(-0.01$ to 0.00$)$ \\
\hline$-0.02(-0.05$ to 0.02$)$ \\
\hline $0.03(-0.08$ to 0.13$)$ \\
\hline $0.01(-0.06$ to 0.08$)$ \\
\hline $0.033(-0.06$ to 0.13$)$ \\
\hline$-0.04(-0.15$ to 0.06$)$ \\
\hline
\end{tabular}

$P$
0.0
0

P value

0.038

0.392

0.076

$<0.001$

0.215

0.556

0.012

0.471

0.018

$<0.001$

0.804

0.331

0.020

0.761

0.281

$<0.001$

0.851

0.464

0.042

0.901

0.691

0.025

0.902

0.595

0.315

0.859

0.914

0.323

0.480

0.406

0.045

0.437

0.351

0.677

0.142

0.342

Statistical test performed on log- or root-square transformed data.

BMI, body mass index; HOMA-B, homeostasis model assessment for $\beta$-cell function; HOMA-IR, homeostasis model assessment for insulin resistance; IGI, insulinogenic index.

(58). Deleskong et al. reported a positive and significant effect of higher vitamin $\mathrm{D}$ concentration in reducing risk of T2D in individuals with prediabetes, but not in those subjects with normal glucose tolerance (59). Chiu et al., in a cohort of healthy glucose-tolerant adults, demonstrated a positive correlation between $25(\mathrm{OH}) \mathrm{D}$ and IS, and a negative effect of hypovitaminosis D on BCF, assessed by an independent, negative, relationship between $25(\mathrm{OH}) \mathrm{D}$ and plasma glucose during a hyperglycemic clamp (60). Moreover, in a large cohort of children and adolescents, Ganji et al. reported an inverse correlation between $25(\mathrm{OH})$ D levels and HOMA-IR (12). Conversely, other studies, carried out both in children and adults, did not document association between vitamin D levels and IR or glycemic control $(9,21,61,62)$. A causal effect relationship between hypovitaminosis D and glycemic control, IR or diabetes risk (22) as well as not even favorable effects of vitamin D supplementation on plasma glucose, plasma insulin and IR or BCF were reported $(24,63,64)$. These contrasting results suggest that several factors, including genetic background (i.e. VDBP polymorphisms), baseline vitamin $\mathrm{D}$ concentration and measurement methods, dose and routes of administration of vitamin D supplementation, influence the activity of vitamin D.

Although available data of the literature are not consistent, the results of our study suggest that, as an 
Table 5 Multivariate linear regression analysis in the total sample for HOMA-IR, HOMA-B, Matsuda index, IGI, derivative control and proportional control using BVD, age, gender, BMI SDS, pubertal stage and seasonality of vitamin D measurement as independent variables.

\begin{tabular}{|c|c|}
\hline Dependent variables & Independent variables \\
\hline \multirow[t]{6}{*}{ HOMA-IR } & BVD \\
\hline & Age \\
\hline & Gender \\
\hline & BMI SDS \\
\hline & Pubertal stage \\
\hline & Seasonality \\
\hline \multirow[t]{6}{*}{ HOMA-B } & BVD \\
\hline & Age \\
\hline & Gender \\
\hline & BMI SDS \\
\hline & Pubertal stage \\
\hline & Seasonality \\
\hline \multirow[t]{6}{*}{ Matsuda index } & BVD \\
\hline & Age \\
\hline & Gender \\
\hline & BMI SDS \\
\hline & Pubertal stage \\
\hline & Seasonality \\
\hline \multirow[t]{6}{*}{ IGI } & BVD \\
\hline & Age \\
\hline & Gender \\
\hline & BMI SDS \\
\hline & Pubertal stage \\
\hline & Seasonality \\
\hline \multirow[t]{6}{*}{ Derivative control } & BVD \\
\hline & Age \\
\hline & Gender \\
\hline & BMI SDS \\
\hline & Pubertal stage \\
\hline & Seasonality \\
\hline \multirow[t]{6}{*}{ Proportional control } & BVD \\
\hline & Age \\
\hline & Gender \\
\hline & BMI SDS \\
\hline & Pubertal stage \\
\hline & Seasonality \\
\hline
\end{tabular}

\begin{tabular}{|c|}
\hline$\beta$ coefficient $(95 \% \mathrm{Cl})$ \\
\hline$-0.05(-0.23$ to 0.13$)$ \\
\hline$-0.02(-0.08$ to 0.03$)$ \\
\hline $0.01(-0.15$ to 0.18$)$ \\
\hline $0.18(0.09-0.27)$ \\
\hline $0.07(-0.08$ to 0.23$)$ \\
\hline $0.05(-0.11$ to 0.21$)$ \\
\hline$-0.15(-0.54$ to 0.24$)$ \\
\hline$-0.02(-0.14$ to 0.10$)$ \\
\hline $0.12(-0.24$ to 0.48$)$ \\
\hline $0.40(0.20-0.61)$ \\
\hline $0.15(-0.19$ to 0.48$)$ \\
\hline$-0.06(-0.41$ to 0.29$)$ \\
\hline $0.13(-0.05$ to 0.30$)$ \\
\hline $0.03(-0.03$ to 0.08$)$ \\
\hline 0.004 ( -0.16 to 0.17$)$ \\
\hline$-0.15(-0.25$ to -0.06$)$ \\
\hline$-0.04(-0.19$ to 0.12$)$ \\
\hline$-0.04(-0.20$ to 0.12$)$ \\
\hline$-0.43(-0.83$ to -0.02$)$ \\
\hline $0.03(-0.11$ to 0.17$)$ \\
\hline$-0.24(-0.65$ to 0.18$)$ \\
\hline $0.27(0.02-0.52)$ \\
\hline$-0.05(-0.17$ to 0.63$)$ \\
\hline $0.23(-0.17$ to 0.63$)$ \\
\hline$-10.4(-30.9$ to 10.1$)$ \\
\hline $1.76(-4.54$ to 8.16$)$ \\
\hline$-9.72(-28.7$ to 9.2$)$ \\
\hline $4.83(-6.9$ to 16.6$)$ \\
\hline $3.5(-14.3$ to 21.4$)$ \\
\hline$-10.5(-28.9$ to 7.9$)$ \\
\hline$-0.17(-0.35$ to 0.02$)$ \\
\hline$-0.01(-0.06$ to 0.05$)$ \\
\hline$-0.10(-0.27$ to 0.07$)$ \\
\hline $0.02(-0.09$ to 0.12$)$ \\
\hline$-0.04(-0.20$ to 0.12$)$ \\
\hline$-0.04(-0.35$ to 0.02$)$ \\
\hline
\end{tabular}

\begin{tabular}{|c|c|}
\hline$P$ value & $R^{2}$ \\
\hline 0.441 & 0.316 \\
\hline 0.973 & \\
\hline 0.480 & \\
\hline$<0.001$ & \\
\hline 0.449 & \\
\hline 0.864 & \\
\hline 0.440 & 0.348 \\
\hline 0.709 & \\
\hline 0.502 & \\
\hline$<0.001$ & \\
\hline 0.387 & \\
\hline 0.732 & \\
\hline 0.108 & 0.228 \\
\hline 0.614 & \\
\hline 0.647 & \\
\hline 0.001 & \\
\hline 0.971 & \\
\hline 0.902 & \\
\hline 0.034 & 0.227 \\
\hline 0.485 & \\
\hline 0.108 & \\
\hline 0.025 & \\
\hline 0.988 & \\
\hline 0.392 & \\
\hline 0.504 & 0.140 \\
\hline 0.540 & \\
\hline 0.358 & \\
\hline 0.244 & \\
\hline 0.735 & \\
\hline 0.761 & \\
\hline 0.082 & 0.132 \\
\hline 0.657 & \\
\hline 0.171 & \\
\hline 0.716 & \\
\hline 0.752 & \\
\hline 0.426 & \\
\hline
\end{tabular}

Statistical test performed on log- or root-square transformed data.

$B M I$, body mass index; BVD, bioavailable vitamin D in 47 subjects genotyped for VDBP variants; HOMA-B, homeostasis model assessment for $\beta$-cell function; HOMA-IR, homeostasis model assessment for insulin resistance; IGI, insulinogenic index.

attempt to reduce the risk to develop glucose metabolism impairment, a periodic monitoring of vitamin D concentration in overweight and obese children and adolescents may be justified as well as the treatment with $25(\mathrm{OH}) \mathrm{D}$ in subjects with vitamin D deficiency or insufficiency (65). Of course, the role of vitamin D supplementation as a potential intervention strategy for the management of IR and T2D in obese children and adolescents needs to be assessed by long-term randomized controlled studies.

The study has some potential limitations: (i) the crosssectional design of the study, that did not allow to verify the causal relationships between vitamin D levels and IS,
IR and BCF; (ii) the lack of data on dietary intake vitamin $\mathrm{D}$ and sun exposure. Nevertheless, the potential impact of vitamin D intake with diet on circulating total vitamin $\mathrm{D}$ should be negligible, due to the really modest intake of vitamin $\mathrm{D}$ in the diet usually reported by overweight and obese children living the same geographical area (66). Moreover, the season of blood test sampling for measuring total vitamin $\mathrm{D}$ was considered in the statistical analysis, as an attempt to take indirectly into account sun exposition, higher in spring and summer and lower in autumn and winter; (iii) ethnicity; this study was conducted in subjects with European ancestry, so that results are not directly exportable to subjects with 
other ethnic backgrounds; (iv) vitamin D dosage was not detected by gold standard metabolite test (HPLC with MS/ MS); (v) serum calcium was not available in our cohort despite no phenotype signs of hypocalcemia were found.

This study has also some strengths: (i) the sample set, including glucose-tolerant, healthy subjects, who were not taking chronic medication, that allows to explore relationships between variables avoiding potential confounders due to co-morbidity, so common in obese adult samples; (ii) the glucose metabolism assessment: in this study, differently from other studies $(67,68,69,70)$ in which the relationship between vitamin $\mathrm{D}$ and glucose metabolism in children was investigated considering just indices derived from fasting insulin and glucose levels, we also considered indices of IS and BCF derived from a modified OGTT, a reliable and little invasive test to evaluate glucose tolerance; (iii) vitamin D status assessment: in this study not only the total vitamin $\mathrm{D}$ measurement was provided but also BVD was estimated by the VDBP polymorphisms, according to Powe et al. equations (35); (iv) PTH analysis lets us establish a significant correlation with total vitamin $\mathrm{D}$ in order to exclude that adiposity could be the only cause of hypovitaminosis D.

In conclusion, overweight and obese children and adolescents have a high rate of vitamin D deficiency and insufficiency and hypovitaminosis D is associated with lower BCF and IS.

\section{Declaration of interest}

The authors declare that there is no conflict of interest that could be perceived as prejudicing the impartiality of this study.

\section{Funding}

Supported by grants (FURMAF2017, FURMAF2018) from the Department of Surgery, Dentistry, Paediatrics, and Gynaecology of the University of Verona to $\mathrm{C} M$.

\section{Acknowledgements}

the authors are sincerely indebted to the children and adolescents who participated in the study and to their families. They thank the dedicated staff of the Pediatric Diabetes and Metabolic Disorders Unit of the University Hospital in Verona for their support during the clinical study.

\section{References}

1 Franchi B, Piazza M, Sandri M, Tenero L, Comberiati P, Boner AL \& Capristo C. 25-Hydroxyvitamin D serum level in children of different ethnicity living in Italy. European Journal of Pediatrics 2015174 749-757. (https://doi.org/10.1007/s00431-014-2451-y)

2 Alemzadeh R, Kichler J, Babar G \& Calhoun M. Hypovitaminosis $\mathrm{D}$ in obese children and adolescents: relationship with adiposity, insulin sensitivity, ethnicity, and season. Metabolism: Clinical and Experimental 200857 183-191. (https://doi.org/10.1016/j. metabol.2007.08.023)

3 Absoud M, Cummins C, Lim MJ, Wassmer E \& Shaw N. Prevalence and predictors of vitamin D insufficiency in children: a Great Britain population based study. PLOS ONE 20116 e22179. (https://doi. org/10.1371/journal.pone.0022179)

4 González-Gross M, Valtueña J, Breidenassel C, Moreno LA, Ferrari M, Kersting M, De Henauw S, Gottrand F, Azzini E, Widhalm K et al. Vitamin D status among adolescents in Europe: the Healthy Lifestyle in Europe by Nutrition in Adolescence study. British Journal of Nutrition 2012107 755-764. (https://doi.org/10.1017/ S0007114511003527)

5 Ciresi A, Cicciò F \& Giordano C. High prevalence of hypovitaminosis $\mathrm{D}$ in Sicilian children affected by growth hormone deficiency and its improvement after 12 months of replacement treatment. Journal of Endocrinological Investigation 201437 631-638. (https://doi. org/10.1007/s40618-014-0084-7)

6 Rovner AJ \& O’Brien KO. Hypovitaminosis D among healthy children in the United States: a review of the current evidence. Archives of Pediatrics and Adolescent Medicine 2008162 513-519. (https://doi.org/10.1001/archpedi.162.6.513)

7 Dong Y, Pollock N, Stallmann-Jorgensen IS, Gutin B, Lan L, Chen TC, Keeton D, Petty K, Holick MF \& Zhu H. Low 25-hydroxyvitamin D levels in adolescents: race, season, adiposity, physical activity, and fitness. Pediatrics 2010125 1104-1111. (https://doi.org/10.1542/ peds.2009-2055)

8 Kumar J, Muntner P, Kaskel FJ, Hailpern SM \& Melamed ML. Prevalence and associations of 25-hydroxyvitamin D deficiency in US children: NHANES 2001-2004. Pediatrics 2009124 e362-e370. (https://doi.org/10.1542/peds.2009-0051)

9 Smotkin-Tangorra M, Purushothaman R, Gupta A, Nejati G, Anhalt H $\&$ Ten S. Prevalence of vitamin D insufficiency in obese children and adolescents. Journal of Pediatric Endocrinology and Metabolism 200720 817-823. (https://doi.org/10.1515/JPEM.2007.20.7.817)

10 Wortsman J, Matsuoka LY, Chen TC, Lu Z \& Holick MF. Decreased bioavailability of vitamin D in obesity. American Journal of Clinical Nutrition 200072 690-693. (https://doi.org/10.1093/ ajcn/72.3.690)

11 Earthman CP, Beckman LM, Masodkar K \& Sibley SD. The link between obesity and low circulating 25-hydroxyvitamin D concentrations: considerations and implications. International Journal of Obesity 201236 387-396. (https://doi.org/10.1038/ijo.2011.119)

12 Ganji V, Zhang X, Shaikh N \& Tangpricha V. Serum 25-hydroxyvitamin D concentrations are associated with prevalence of metabolic syndrome and various cardiometabolic risk factors in US children and adolescents based on assay-adjusted serum 25-hydroxyvitamin D data from NHANES 2001-2006. American Journal of Clinical Nutrition 201194 225-233. (https://doi. org/10.3945/ajcn.111.013516)

13 Miraglia del Giudice E, Grandone A, Cirillo G, Capristo C, Marzuillo P, Di Sessa A, Umano GR, Ruggiero L \& Perrone L. Bioavailable vitamin D in obese children: the role of insulin resistance. Journal of Clinical Endocrinology and Metabolism 2015100 3949-3955. (https://doi.org/10.1210/jc.2015-2973)

14 Johnson JA, Grande JP, Roche PC \& Kumar R. Immunohistochemical localization of the $1,25(\mathrm{OH}) 2 \mathrm{D} 3$ receptor and calbindin D28k in human and rat pancreas. American Journal of Physiology 1994267 E356-E360. (https://doi.org/10.1152/ajpendo.1994.267.3.E356)

15 Maestro B, Molero S, Bajo S, Dávila N \& Calle C. Transcriptional activation of the human insulin receptor gene by 1,25-dihydroxyvitamin D(3). Cell Biochemistry and Function 200220 227-232. (https://doi.org/10.1002/cbf.951)

16 Maestro B, Dávila N, Carranza MC \& Calle C. Identification of a vitamin $\mathrm{D}$ response element in the human insulin receptor gene promoter. Journal of Steroid Biochemistry and Molecular Biology $2003 \mathbf{8 4}$ 223-230. (https://doi.org/10.1016/S0960-0760(03)00032-3) 
17 Calle C, Maestro B \& García-Arencibia M. Genomic actions of 1,25-dihydroxyvitamin D3 on insulin receptor gene expression, insulin receptor number and insulin activity in the kidney, liver and adipose tissue of streptozotocin-induced diabetic rats. BMC Molecular Biology 20089 65. (https://doi.org/10.1186/1471-2199-9-65)

18 Manna P \& Jain SK. Vitamin D up-regulates glucose transporter 4 (GLUT4) translocation and glucose utilization mediated by cystathionine- $\gamma$-lyase (CSE) activation and H2S formation in 3T3L1 adipocytes. Journal of Biological Chemistry 2012287 42324-42332. (https://doi.org/10.1074/jbc.M112.407833)

19 Sooy K, Schermerhorn T, Noda M, Surana M, Rhoten WB, Meyer M, Fleischer N, Sharp GW \& Christakos S. Calbindin-D(28k) controls $[\mathrm{Ca}(2+)](\mathrm{i})$ and insulin release. Evidence obtained from calbindin$\mathrm{d}(28 \mathrm{k})$ knockout mice and beta cell lines. Journal of Biological Chemistry 1999274 34343-34349. (https://doi.org/10.1074/ jbc.274.48.34343)

20 Cheng Q, Li YC, Boucher BJ \& Leung PS. A novel role for vitamin D: modulation of expression and function of the local reninangiotensin system in mouse pancreatic islets. Diabetologia 201154 2077-2081. (https://doi.org/10.1007/s00125-011-2100-1)

21 Leung PS. The potential protective action of vitamin D in hepatic insulin resistance and pancreatic islet dysfunction in type 2 diabetes mellitus. Nutrients 20168 147. (https://doi.org/10.3390/nu8030147)

22 Ye Z, Sharp SJ, Burgess S, Scott RA, Imamura F; InterAct Consortium, Langenberg C, Wareham NJ \& Forouhi NG \& Forouhi NG. Association between circulating 25-hydroxyvitamin D and incident type 2 diabetes: a Mendelian randomisation study. Lancet: Diabetes and Endocrinology 20153 35-42. (https://doi.org/10.1016/S22138587(14)70184-6)

23 Ryu OH, Lee S, Yu J, Choi MG, Yoo HJ \& Mantero F. A prospective randomized controlled trial of the effects of vitamin D supplementation on long-term glycemic control in type 2 diabetes mellitus of Korea. Endocrine Journal 201461 167-176. (https://doi. org/10.1507/endocrj.EJ13-0356)

24 Elkassaby S, Harrison LC, Mazzitelli N, Wentworth JM, Colman PG, Spelman T \& Fourlanos S. A randomized controlled trial of high dose vitamin D in recent-onset type 2 diabetes. Diabetes Research and Clinical Practice 2014106 576-582. (https://doi.org/10.1016/j. diabres.2014.08.030)

25 Ashraf AP, Huisingh C, Alvarez JA, Wang X \& Gower BA. Insulin resistance indices are inversely associated with vitamin $\mathrm{D}$ binding protein concentrations. Journal of Clinical Endocrinology and Metabolism 201499 178-183. (https://doi.org/10.1210/jc.2013-2452)

26 Ferira AJ, Laing EM, Hausman DB, Hall DB, McCabe GP, Martin BR, Hill Gallant KM, Warden SJ, Weaver CM, Peacock M et al. Vitamin D supplementation does not impact insulin resistance in black and white children. Journal of Clinical Endocrinology and Metabolism 2016 101 1710-1718. (https://doi.org/10.1210/jc.2015-3687)

27 de Onis M, Onyango AW, Borghi E, Siyam A, Nishida C \& Siekmann J. Development of a WHO growth reference for school-aged children and adolescents. Bulletin of the World Health Organization 200785 660-667. (https://doi.org/10.2471/ blt.07.043497)

28 American Diabetes Association. 2. Classification and diagnosis of diabetes. Diabetes Care 201740 (Supplement 1) S11-S24. (https://doi. org/10.2337/dc17-S005)

29 Corica D, Aversa T, Valenzise M, Messina MF, Alibrandi A, De Luca F $\&$ Wasniewska M. Does family history of obesity, cardiovascular, and metabolic diseases influence onset and severity of childhood obesity? Frontiers in Endocrinology 20189 187. (https://doi.org/10.3389/ fendo.2018.00187)

30 Maffeis C, Grezzani A, Pietrobelli A, Provera S \& Tatò L. Does waist circumference predict fat gain in children? International Journal of Obesity and Related Metabolic Disorders 200125 978-983. (https://doi. org/10.1038/sj.ijo.0801641)
31 Maffeis C, Banzato C, Talamini G \& Obesity Study Group of the Italian Society of Pediatric Endocrinology and Diabetology. Waistto-height ratio, a useful index to identify high metabolic risk in overweight children. Journal of Pediatrics 2008152 207-213. (https:// doi.org/10.1016/j.jpeds.2007.09.021)

32 Tanner JM. Growth at Adolescence, p. 212. Oxford: Blackwell Scientific Publications, 1955.

33 Flynn JT, Kaelber DC, Baker-Smith CM, Blowey D, Carroll AE, Daniels SR, de Ferranti SD, Dionne JM, Falkner B, Flinn SK et al. Clinical Practice Guideline for screening and management of high blood pressure in children and adolescents. Pediatrics 2017140 e20171904. (https://doi.org/10.1542/peds.2017-1904)

34 Bonadonna RC, Heise T, Arbet-Engels C, Kapitza C, Avogaro A, Grimsby J, Zhi J, Grippo JF \& Balena R. Piragliatin (RO4389620), a novel glucokinase activator, lowers plasma glucose both in the postabsorptive state and after a glucose challenge in patients with type 2 diabetes mellitus: a mechanistic study. Journal of Clinical Endocrinology and Metabolism 201095 5028-5036. (https://doi. org/10.1210/jc.2010-1041)

35 Matthews DR, Hosker JP, Rudenski AS, Naylor BA, Treacher DF \& Turner RC. Homeostasis model assessment: insulin resistance and beta-cell function from fasting plasma glucose and insulin concentrations in man. Diabetologia 198528 412-419. (https://doi. org/10.1007/BF00280883)

36 Wallace TM, Levy JC \& Matthews DR. Use and abuse of HOMA modeling. Diabetes Care 200427 1487-1495. (https://doi. org/10.2337/diacare.27.6.1487)

37 Phillips DI, Clark PM, Hales CN \& Osmond C. Understanding oral glucose tolerance: comparison of glucose or insulin measurements during the oral glucose tolerance test with specific measurements of insulin resistance and insulin secretion. Diabetic Medicine 199411 286-292. (https://doi.org/10.1111/j.1464-5491.1994.tb00273.x)

38 Matsuda M \& DeFronzo RA. Insulin sensitivity indices obtained from oral glucose tolerance testing: comparison with the euglycemic insulin clamp. Diabetes Care 199922 1462-1470. (https://doi. org/10.2337/diacare.22.9.1462)

39 Bonetti S, Trombetta M, Boselli ML, Turrini F, Malerba G, Trabetti E, Pignatti PF, Bonora E \& Bonadonna RC. Variants of GCKR affect both beta-cell and kidney function in patients with newly diagnosed type 2 diabetes: the Verona newly diagnosed type 2 diabetes study 2. Diabetes Care 201134 1205-1210. (https://doi.org/10.2337/dc102218)

40 Saggese G, Vierucci F, Prodam F, Cardinale F, Cetin I, Chiappini E, De' Angelis GL, Massari M, Miraglia Del Giudice E, Miraglia Del Giudice M et al. Vitamin D in pediatric age: consensus of the Italian Pediatric Society and the Italian Society of Preventive and Social Pediatrics, jointly with the Italian Federation of Pediatricians. Italian Journal of Pediatrics 201844 51. (https://doi.org/10.1186/s13052-0180488-7)

41 Powe CE, Evans MK, Wenger J, Zonderman AB, Berg AH, Nalls M, Tamez H, Zhang D, Bhan I, Karumanchi SA et al. Vitamin D-binding protein and vitamin D status of black Americans and white Americans. New England Journal of Medicine 2013369 1991-2000. (https://doi.org/10.1056/NEJMoa1306357)

42 Hochberg B. Controlling the false discovery rate: a practical and powerful approach to multiple testing. Journal of the Royal Statistical Society 199557 289-300. (https://doi.org/10.2307/2346101)

43 Chagas CE, Borges MC, Martini LA \& Rogero MM. Focus on vitamin D, inflammation and type 2 diabetes. Nutrients 20124 52-67. (https://doi.org/10.3390/nu4010052)

44 Forouhi NG, Luan J, Cooper A, Boucher BJ \& Wareham NJ. Baseline serum 25-hydroxy vitamin $\mathrm{D}$ is predictive of future glycemic status and insulin resistance: the Medical Research Council Ely Prospective Study 1990-2000. Diabetes 200857 2619-2625. (https://doi. org/10.2337/db08-0593) 
45 Kayaniyil S, Retnakaran R, Harris SB, Vieth R, Knight JA, Gerstein HC, Perkins BA, Zinman B \& Hanley AJ. Prospective associations of vitamin $\mathrm{D}$ with beta-cell function and glycemia: the PROspective Metabolism and ISlet cell Evaluation (PROMISE) cohort study. Diabetes 201160 2947-2953. (https://doi.org/10.2337/db110465)

46 Cheng Q, Law PK, de Gasparo M \& Leung PS. Combination of the dipeptidyl peptidase IV inhibitor LAF237 [(S)-1-[(3-hydroxy-1adamantyl)ammo]acetyl-2-cyanopyrrolidine] with the angiotensin II type 1 receptor antagonist valsartan [N-(1-oxopentyl)-N-[[2'(1H-tetrazol-5-yl)-[1,1'-biphenyl]-4-yl]methyl]-L-valine] enhances pancreatic islet morphology and function in a mouse model of type 2 diabetes. Journal of Pharmacology and Experimental Therapeutics 2008 327 683-691. (https://doi.org/10.1124/ipet.108.142703)

47 Cheng Q, Boucher BJ \& Leung PS. Modulation of hypovitaminosis D-induced islet dysfunction and insulin resistance through direct suppression of the pancreatic islet renin-angiotensin system in mice. Diabetologia 201356 553-562. (https://doi.org/10.1007/s00125-0122801-0)

48 Kitade H, Chen G, Ni Y \& Ota T. Nonalcoholic fatty liver disease and insulin resistance: new insights and potential new treatments. Nutrients 20179 E387. (https://doi.org/10.3390/nu9040387)

49 Li R, Guo E, Yang J, Li A, Yang Y, Liu S, Liu A \& Jiang X. 1,25(OH)2D3 attenuates hepatic steatosis by inducing autophagy in mice. Obesity 201725 561-571. (https://doi.org/10.1002/oby.21757)

50 Zhu CG, Liu YX, Wang H, Wang BP, Qu HQ, Wang BL \& Zhu M. Active form of vitamin D ameliorates non-alcoholic fatty liver disease by alleviating oxidative stress in a high-fat diet rat model. Endocrine Journal 201764 663-673. (https://doi.org/10.1507/endocrj. EJ16-0542)

51 Cheng S, So WY, Zhang D, Cheng Q, Boucher BJ \& Leung PS. Calcitriol reduces hepatic triglyceride accumulation and glucose output Through Ca2+/CaMKK $\beta / A M P K$ activation Under insulinresistant conditions in type 2 diabetes mellitus. Current Molecular Medicine 201616 747-758. (https://doi.org/10.2174/1566524016666 160920111407)

52 Targher G, Bertolini L, Scala L, Cigolini M, Zenari L, Falezza G \& Arcaro G. Associations between serum 25-hydroxyvitamin D3 concentrations and liver histology in patients with non-alcoholic fatty liver disease. Nutrition, Metabolism, and Cardiovascular Diseases 200717 517-524. (https://doi.org/10.1016/j.numecd.2006.04.002)

53 Kwok RM, Torres DM \& Harrison SA. Vitamin D and nonalcoholic fatty liver disease (NAFLD): is it more than just an association? Hepatology 201358 1166-1174. (https://doi.org/10.1002/ hep.26390)

54 Hourigan SK, Abrams S, Yates K, Pfeifer K, Torbenson M, Murray K, Roth CL, Kowdley K, Scheimann AO \& NASH CRN. Relation between vitamin $\mathrm{D}$ status and nonalcoholic fatty liver disease in children. Journal of Pediatric Gastroenterology and Nutrition $201560396-404$. (https://doi.org/10.1097/MPG.0000000000000598)

55 Wang N, Chen C, Zhao L, Chen Y, Han B, Xia F, Cheng J, Li Q \& Lu Y. Vitamin D and nonalcoholic fatty liver disease: bi-directional Mendelian randomization analysis. EBioMedicine 201828 187-193. (https://doi.org/10.1016/j.ebiom.2017.12.027)

56 Barchetta I, Del Ben M, Angelico F, Di Martino M, Fraioli A, La Torre G, Saulle R, Perri L, Morini S, Tiberti C et al. No effects of oral vitamin $\mathrm{D}$ supplementation on non-alcoholic fatty liver disease in patients with type 2 diabetes: a randomized, double-blind, placebocontrolled trial. BMC Medicine 201614 92. (https://doi.org/10.1186/ s12916-016-0638-y)
57 Kitson MT, Pham A, Gordon A, Kemp W \& Roberts SK. High-dose vitamin D supplementation and liver histology in NASH. Gut 2016 65 717-718. (https://doi.org/10.1136/gutjnl-2015-310417)

58 Parker J, Hashmi O, Dutton D, Mavrodaris A, Stranges S, Kandala NB, Clarke A \& Franco OH. Levels of vitamin D and cardiometabolic disorders: systematic review and meta-analysis. Maturitas 201065 225-236. (https://doi.org/10.1016/j.maturitas.2009.12.013)

59 Deleskog A, Hilding A, Brismar K, Hamsten A, Efendic S \& Östenson CG. Low serum 25-hydroxyvitamin D level predicts progression to type 2 diabetes in individuals with prediabetes but not with normal glucose tolerance. Diabetologia 201255 1668-1678. (https://doi.org/10.1007/s00125-012-2529-x)

60 Chiu KC, Chu A, Go VL \& Saad MF. Hypovitaminosis D is associated with insulin resistance and beta cell dysfunction. American Journal of Clinical Nutrition 200479 820-825. (https://doi.org/10.1093/ ajcn/79.5.820)

61 Reilly JJ, Methven E, McDowell ZC, Hacking B, Alexander D, Stewart L \& Kelnar CJ. Health consequences of obesity. Archives of Disease in Childhood 200388 748-752. (https://doi.org/10.1136/ adc.88.9.748)

62 Dietz WH. Health consequences of obesity in youth: childhood predictors of adult disease. Pediatrics 1998101 518-525.

63 Afzal S, Bojesen SE \& Nordestgaard BG. Low 25-hydroxyvitamin $\mathrm{D}$ and risk of type 2 diabetes: a prospective cohort study and metaanalysis. Clinical Chemistry 201359 381-391. (https://doi. org/10.1373/clinchem.2012.193003)

64 Mattila C, Knekt P, Männistö S, Rissanen H, Laaksonen MA, Montonen J \& Reunanen A. Serum 25-hydroxyvitamin D concentration and subsequent risk of type 2 diabetes. Diabetes Care 200730 2569-2570. (https://doi.org/10.2337/dc07-0292)

65 Gagnon C, Lu ZX, Magliano DJ, Dunstan DW, Shaw JE, Zimmet PZ, Sikaris K, Grantham N, Ebeling PR \& Daly RM. Serum 25-hydroxyvitamin $\mathrm{D}$, calcium intake, and risk of type 2 diabetes after 5 years: results from a national, population-based prospective study (the Australian Diabetes, Obesity and Lifestyle study). Diabetes Care 201134 1133-1138. (https://doi.org/10.2337/dc10-2167)

66 Jehle S, Lardi A, Felix B, Hulter HN, Stettler C \& Krapf R. Effect of large doses of parenteral vitamin $\mathrm{D}$ on glycaemic control and calcium/phosphate metabolism in patients with stable type 2 diabetes mellitus: a randomised, placebo-controlled, prospective pilot study. Swiss Medical Weekly 2014144 w13942. (https://doi. org/10.4414/smw.2014.13942)

67 Pittas AG, Dawson-Hughes B, Li T, Van Dam RM, Willett WC, Manson JE \& Hu FB. Vitamin D and calcium intake in relation to type 2 diabetes in women. Diabetes Care 200629 650-656. (https:// doi.org/10.2337/diacare.29.03.06.dc05-1961)

68 Pittas AG, Harris SS, Stark PC \& Dawson-Hughes B. The effects of calcium and vitamin D supplementation on blood glucose and markers of inflammation in nondiabetic adults. Diabetes Care 2007 30 980-986. (https://doi.org/10.2337/dc06-1994)

69 Mitri J, Dawson-Hughes B, Hu FB \& Pittas AG. Effects of vitamin $\mathrm{D}$ and calcium supplementation on pancreatic beta cell function, insulin sensitivity, and glycemia in adults at high risk of diabetes: the calcium and vitamin D for diabetes mellitus (CaDDM) randomized controlled trial. American Journal of Clinical Nutrition 201194 486-494. (https://doi.org/10.3945/ajcn.111.011684)

70 Sabherwal S, Bravis V \& Devendra D. Effect of oral vitamin D and calcium replacement on glycaemic control in South Asian patients with type 2 diabetes. International Journal of Clinical Practice 201064 1084-1089. (https://doi.org/10.1111/j.1742-1241.2010.02372.x)
Received 15 May 2019

Revised version received 9 July 2019

Accepted 13 August 2019 